\title{
Groundwater Quality Mapping using Geographic Information System: A Case Study of District Thatta, Sindh
}

\author{
GHULAM SHABIR SOLANGI*, ALTAF ALI SIYAL*, MUHAMMAD MUNIR BABAR*, AND PIRAH SIYAL** \\ RECEIVED ON 21.04.2017 ACCEPTED ON 29.05.2017
}

\begin{abstract}
Access to safe and affordable drinking water for all is an important goal of SDGs (Sustainable Development Goals). Degradation of water quality of coastal aquifers is a major concern throughout the world including the Indus River delta. Looking at the present changing climate scenario, the study was conducted to assess and map the spatial variation in the groundwater quality of district Thatta using GIS (Geographic Information System). The groundwater samples from hundred (100) randomly selected hand pumps of the district were collected such that all union councils of the district were sampled. The water samples were analyzed for different physicochemical parameters, i.e. taste, color, odor, $\mathrm{pH}$, turbidity, EC (Electrical Conductivity), calcium, magnesium, total hardness, chloride, total dissolved solids, and arsenic using standard laboratory techniques. The results of water analysis revealed that 85\% of the groundwater samples had TDS (Total Dissolved Solids) concentration beyond the permissible limit described by WHO (World Health Organization). Whereas, all the groundwater samples had chloride concentration beyond permissible limit of $250 \mathrm{mg} / \mathrm{l}$. Analysis for arsenic revealed that only $20 \%$ of groundwater samples had a concentration higher than the safe limit of $10 \mathrm{ppb}$. The study indicated that in most of the areas, the groundwater quality was not as per drinking standards prescribed by WHO, hence was not suitable for drinking purpose. The GIS maps of groundwater quality parameters were prepared using spatial interpolation Kriging tool. These maps provide the visual analysis and interpretation of spatial variability of different groundwater quality parameters, hence are supportive in monitoring and managing the vulnerability of groundwater contamination.
\end{abstract}

Key Words: Coastal Aquifers, Arsenic, Chlorides, Physicochemical Properties, Geographic Information System.

\section{INTRODUCTION}

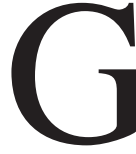

roundwater is considered as one of the most vital renewable and extensively circulated resources of the earth which are also an important source of water supply throughout the globe [1]. It is used for domestic, agriculture, industrial and many other human needs. Human health isdirectly associated with groundwater; therefore, its quality is of a prime importance for human health [2]. In areas where potable water resources are limited, an accurate and reliable estimateof sustainable use or yield is critical [3].

Corresponding Author (E-Mail: siyal@yahoo.com)

* US-Pakistan Center for Advanced Studies in Water, Mehran University of Engineering \& Technology, Jamshoro.

** National Centre of Excellence in Analytical Chemistry, University of Sindh, Jamshoro.

Mehran University Research Journal of Engineering \& Technology, Volume 36, No. 4, October, 2017 [p-ISSN: 0254-7821, e-ISSN: 2413-7219] 
Specifically, optimal or sustainable groundwater resource userequires setting upper limits on water withdrawal (or sustainable yield) to avoid compromising the source [4]. Estimates reveal that in Pakistan 30\% of all diseases and $40 \%$ of all deaths occur due to use of contaminated water while every fifth person experiences illness because of contaminated water [5]. It is also reported that more than three million people encounter the water-borne diseases every year while 0.1 million die [6].

In coastal areas, up to one billion people utilize groundwater as the major source of drinking throughout the globe [7]. In such areas, seawater intrusion is the main environmental issue for contamination of groundwater [8-10]. The groundwater becomes unsuitable for domestic, irrigation as well as industrial purposes when mixed with salty water even in very small quantities [11]. In coastal aquifers, increase in seawater intrusion is an interrelated and dynamic phenomenon which depends on different parameters such as recharge, groundwater extraction from coastal aquifers, and the topography of such aquifers [12-13]. The unplanned and unsystematic groundwater withdrawal from aquifers is the primary reason of groundwater salinization in coastal areas [14]. Because of environmental change, sea level is rising that is also one of the fundamental cause of seawater intrusion and contamination of the coastal aquifers [15-16]. The deteriorating quality of water in developing countries has caused diarrhea [17], hepatitis E [18], dental caries and oral hygiene [19], anemia in children [20], reducing intelligence in children, and brain functioning and development [21].

In Pakistan, more than $60 \%$ of the population utilizes groundwater for drinking purpose [22] and the degradation of groundwater is one of the significant concerns caused by overexploitation of the groundwater resources and discharge of untreated polluted wastes into the water bodies. Sixty-Eight percent (68\%) rural population of Pakistan is drinking the water of poor quality [23]. One hundred million cases of diarrheal diseases are being registered in hospitals of Pakistan within 1 year [24]. It is also reported that in Pakistan, around 0.25 million children die due to drinking of contaminated water [22]. Polluted water, purity, and hygiene practices are the fundamental cause of most diarrheal cases, the primary cause of around 0.25 million children die under the age of five years annually [22]. According to a study led by UNICEF, around $20-40 \%$ of the hospital beds in Pakistan were occupied by patients experiencing waterborne diseases,such as, typhoid, dysentery, cholera, and hepatitis, which are the reasons of 33\% of all deaths [25]. The accessibility of safe and affordable drinking water significantly affects the waterborne diseases.

The southern Sindh province of Pakistan adjoins the Arabian Sea coast where drinking water quality is deteriorating due to the dumping of industrial and urban waste and use of agrochemicals and yet has limited freshwater resources [26]. The groundwater quality is badly affected by salinity, arsenic, fluoride and microbial pollution, which further deteriorates in low-lying, deltaic and floodplains of Sindh [27]. In these areas, people mostly depend on the groundwater for drinking and irrigation purpose because of low precipitation and reduced flow of Indus River [28]. In the coastal areas, seawater intrusion further degrades the quality of groundwater [2]. The contamination in groundwater in most of the areas of the Thatta district is due to seawater intrusion, as seawater contains many trace metals [29]. Therefore, monitoring of quality of drinking water is a key factor for control of waterborne diseases in such areas.

Initial studies on arsenic distribution in the groundwater show that high arsenic concentrations (10-600), exceeding WHO [30] permissible limit of 10

Mehran University Research Journal of Engineering \& Technology, Volume 36, No. 4, October, 2017 [p-ISSN: 0254-7821, e-ISSN: 2413-7219] 
ppb, occur in the groundwater of Tando Mohammad Khan, Thatta, Mitiari, Khairpur and other parts of Sindh province of Pakistan [30-33]. Memon et. al. [26] conducted a study in the southern districts i.e. Thatta, Badin, and Tharparkar of Sindh province of Pakistan and reported about some common diseases like gastroenteritis, diarrhea, vomiting, kidney, and skin problems found in these areas. The review of the literature indicated that so far only a few studieshave been conducted on groundwater quality of Thatta district. Some studies were focused only on physicochemical parameters while in other studies onlythe biological parameters in groundwater were observed. However, these studies did not consider the entire district but considered only some major cities of the district only. However, detailed studies regarding the spatial variation of the groundwater quality in coastal districts of Sindh are still lacking.

GIS is an effective tool widely used for monitoring and mapping of the water quality, evaluating the spatial variability of water quality and detecting the environmental change [34]. Considering the concerns of civil society about the quality of groundwater of Thatta district, the present study was carried out. Distinctive physicochemical parameters of groundwater were analyzed and compared the standard allowable limits described by WHO to assess the quality of groundwater for drinking purpose. The study accordingly planned to assess the groundwater quality and develop a spatial distribution database using GIS interpolation techniques, based on the results of physicochemical analysis of groundwater of district Thatta. Theresults obtained from the study will be useful for government, policy makers as well as the public to be aware of existing groundwater contamination and will besupportive for the monitoring and managing the vulnerability of groundwater contamination in the district.

\section{MATERIALS AND METHOD}

\subsection{The Study Area}

Thatta district comprises of four talukas viz. Thatta, Keti Bander, Ghorabari, and Mirpur Sakro. It spreads over a geographical area of about 8390 square kilometers (839100 hectares). As per the 1998 census, the total population of these four talukas was 0.6 million. The district is situated where the Indus River flows into the Arabian Sea, having Latitude of $23^{\circ} 56^{\prime} 54^{\prime \prime}$ to $25^{\circ} 26^{\prime} 40^{\prime \prime} \mathrm{N}$ and Longitude of $67^{\circ} 8^{\prime} 58^{\prime \prime}$ to $68^{\circ} 20^{\prime} 59^{\prime \prime E}$. It lies in the southwestern part of Sindh province of Pakistan (Fig. 1). Jamshoro district is in North and West, Sujawal and Tando Muhammad Khan districts in the East, Karachi district lies on the West while district Hyderabad shares Northeast boundary of the district Thatta. The climate of the district is dry with an average annual rainfall about $220 \mathrm{~mm}$ [35] most of which falls during monsoon which spans from June to September. The temperature ranges between $23.8-28.7^{\circ} \mathrm{C}$ [35-36]. The agriculture in the area depends on both the surface water (Indus River canals) and groundwater. It is a part of Lower Indus alluvial and a deltaic plain covered by thick alluvial deltaic sediments which host the aquifers in the area [37]. Its soil constitutes fine-grained sediments, rich in organic matter containing a high amount of arsenic, which is supposed to become part of aquifers by various geochemical processes [38-39]. Most of the residents of the district use groundwater extracted from the handpumps drilled into shallow aquifers down to 5-12 m for their drinking and other daily water use.

\subsection{Analysis of the Groundwater Samples}

The groundwater samples were collected from randomly selected 100 hand pumps installed at public places i.e. schools, bus stops, restaurants as well as at the residential places. These hand pumps were extensively used by the people for extracting groundwater for their domestic use. Groundwater sampling locations were recorded using the handheld

Mehran University Research Journal of Engineering \& Technology, Volume 36, No. 4, October, 2017 [p-ISSN: 0254-7821, e-ISSN: 2413-7219] 
Garmin GPS (62s). Thus, about three samples from each of the 27 union councils of the district were collected as shown in Fig. 2. The groundwater samples were collected in one-litre polythene bottles by observing standard sample collection methods. The bottles were washed and rinsed properly with distilled water to remove any possible contamination. During the study, it was learned that the installation depth of hand pumps varied from 5-15 m throughout the district. According to the depth of hand pumps, the purging process was applied. If the hand pump was bored at $10 \mathrm{~m}$ depth, it needed 30 strokes for its purging. After purging, the polythene bottles and their caps were washed with the same water and then samples were collected in bottles for getting maximum accuracy in results. The samples were collected from July-December 2016. All the collected groundwater samples were coded, sealed and preserved properly, then shifted to the laboratory for physicochemical analysis.

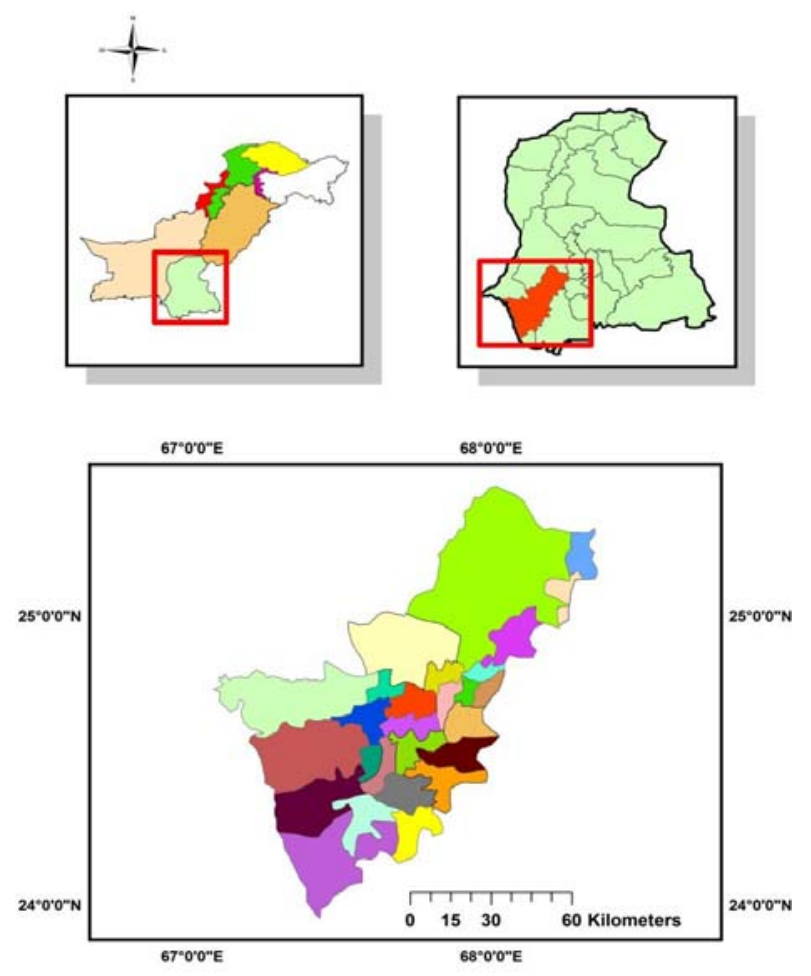

FIG. 1. LOCATION MAP OF THE STUDY AREA

\subsection{Water Quality Parameters}

The groundwater samples were analyzed for different physicochemical parameters viz. taste, color, odor, turbidity, pH, EC, TDS, C1 (Chloride), Ca (Calcium), Mg (Magnesium), TH (Total Hardness), and arsenic using available standard laboratory methods. The results of groundwater quality parameters were compared with permissible limits prescribed by WHO for the safe drinking water. Materials and methods used for determining groundwater quality parameters of Thatta district are described in Table 1.

\subsection{Preparation of Groundwater Quality Thematic Maps}

ArcGIS 10.3.1 was used to develop spatial distribution groundwater quality thematic maps of the district for various physicochemical parameters. The resulting analysis of physicochemical parameters was stored in MS Excel spreadsheet along with location coordinates. The excel sheet was imported in ArcMap 10.3.1 through

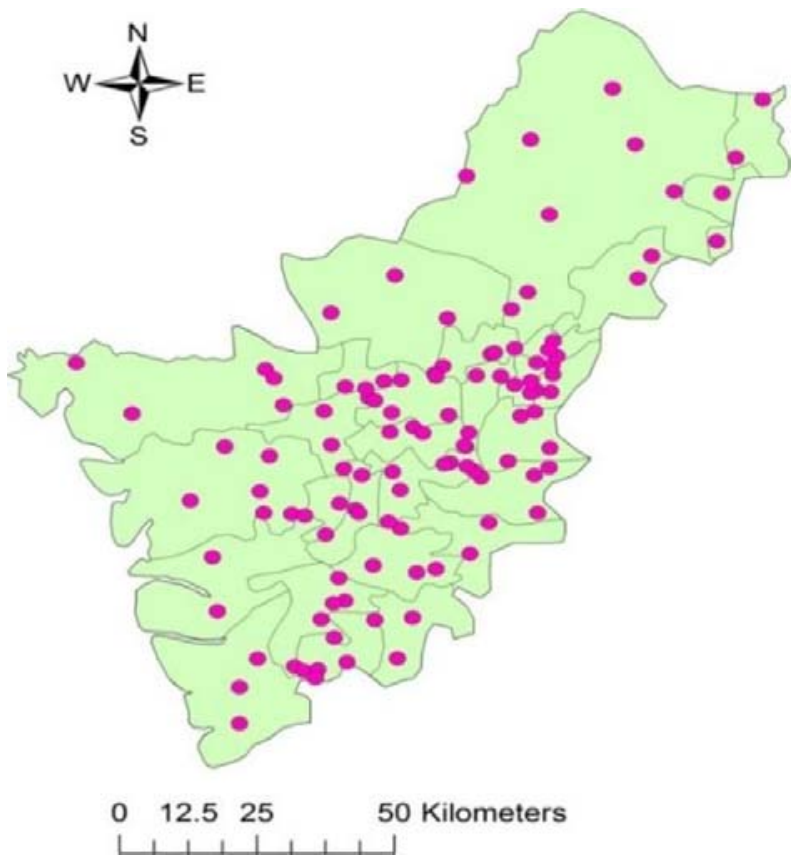

FIG. 2. GROUNDWATER SAMPLING LOCATION

Mehran University Research Journal of Engineering \& Technology, Volume 36, No. 4, October, 2017 [p-ISSN: 0254-7821, e-ISSN: 2413-7219] 
add option. The spatial variation of each of the groundwater quality parameter was interpolated for the whole district using spatial interpolation "Kriging” tool and then extracting the AOI (Area of Interest) using "Extraction by mask" tool. Thus, spatial distribution thematic maps of the groundwater of district Thatta for various physicochemical parameters viz. taste, $\mathrm{pH}$, color, odor, turbidity, electrical conductivity, calcium, magnesium, total hardness, chloride, total dissolved solids, and arsenic were prepared.

\section{RESULTS AND DISCUSSION}

The water quality maps are useful for assessing the suitability of water for drinking purpose [1]. These maps provide the visual interpretation of spatial variability of different groundwater quality parameters, hence are helpful in monitoring and managing the vulnerability of groundwater contamination.

\subsection{Taste, Color, Odor, and pH}

The results of the study revealed that about $55 \%$ of the groundwater samples of the district Thatta had bitter and salty taste, while $16 \%$ samples had color values greater than the permissible limit of 15 TCU. However, odor and $\mathrm{pH}$ in most of the water samples were within the permissible limits set by WHO for human consumption. Spatial distribution of these parameters is shown in Fig. 3(a-d).

\subsection{Turbidity}

The groundwater quality analysis revealed that the turbidity in the groundwater of the study area ranged from 0.5-34.1 NTU with a mean value of 5.4 NTU while its permissible limit for drinking water is 5 NTU [30]. The suspended particles in water strengthen the connection of overwhelming metals and other dangerous minerals and pesticides, making the water cloudy and opaque, thus create human health issues [29]. The spatial distribution of turbidity in the study area is shown in Fig. 4. The Fig. 4 shows that areas near to Gharo town have some turbidity might be due to use of poor quality strainer filter material.

TABLE 1. WATER QUALITY PARAMETERS AND METHODS ADOPTED FOR ANALYSIS

\begin{tabular}{|c|c|}
\hline Parameters & Test method \\
\hline Colour (TCU*) & Sensory Test \\
\hline Odour & Sensory Test \\
\hline Taste (bitter, salty, sour and sweet) & Sensory Test \\
\hline Turbidity (NTU*) & Turbidity Meter, Lamotte, Model 2008, USA \\
\hline Calcium (mg/l) & 3500-Ca-D, Standard method (1992) \\
\hline Chlorides (mg/l) & Titration (Silver Nitrate), Standard Method (1992) \\
\hline Hardness (mg/l) & EDTA Titration, Standard Method (1992) \\
\hline Magnesium (mg/l) & 2340-C, Standard Method (1992) \\
\hline pH at 25oC & pH Meter, Hanna Instrument, Model 8519, Italy \\
\hline TDS (mg/l) & TDS meter \\
\hline Arsenic (mg/l) & Merck Test Kit (0-0.5 mg/L) 1.17927.0001 \\
\hline *TCU = True Colour Units, NTU $=$ Nephelometric Turbidity Unit (s) \\
\hline
\end{tabular}

Mehran University Research Journal of Engineering \& Technology, Volume 36, No. 4, October, 2017 [p-ISSN: 0254-7821, e-ISSN: 2413-7219] 


\subsection{Electrical Conductivity}

EC is the most significant parameter used as the primary index to decide the suitability of water for drinking as well as for irrigation purpose [40-41]. For drinking purpose, its permissible limit is $0.7 \mathrm{dS} / \mathrm{m}$ [30]. For the study area, EC values ranged from $0.5-26.1 \mathrm{dS} / \mathrm{m}$ with an average value of $2.4 \mathrm{dS} / \mathrm{m}$. The higher values of the EC along coastal belt might be due to the entry of highly saline water from the Arabian Sea into aquifers of the study area. Similar results were reported by Husain et. al. [27] while conducting a study in the Indus deltaic plain. Higher concentration of the conductivity increases the destructive nature of the water [29]. Fig. 5 demonstrates the spatial distribution of EC in groundwater of the Thatta district which shows the higher electrical conductivity of groundwater in almost all places of the study area.
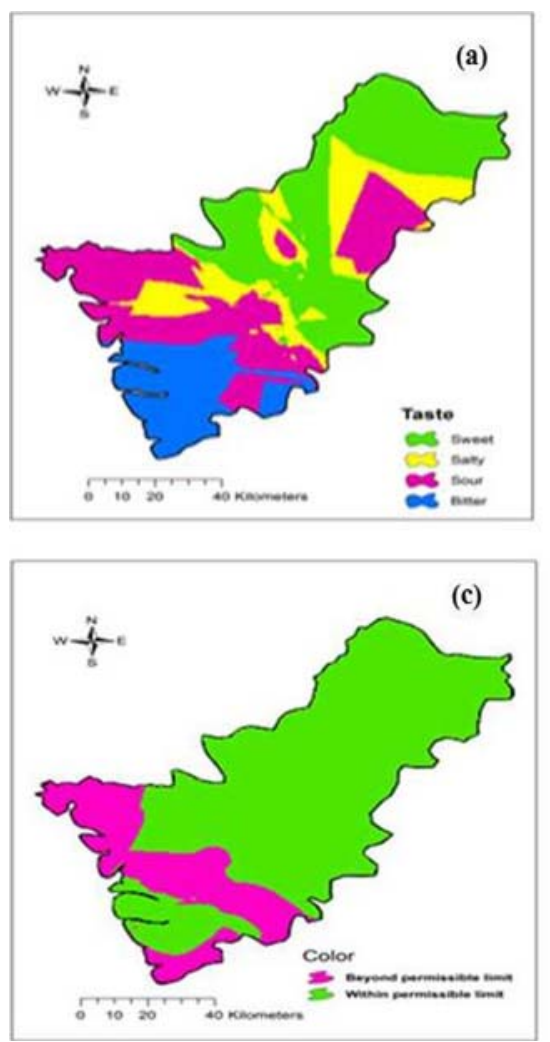

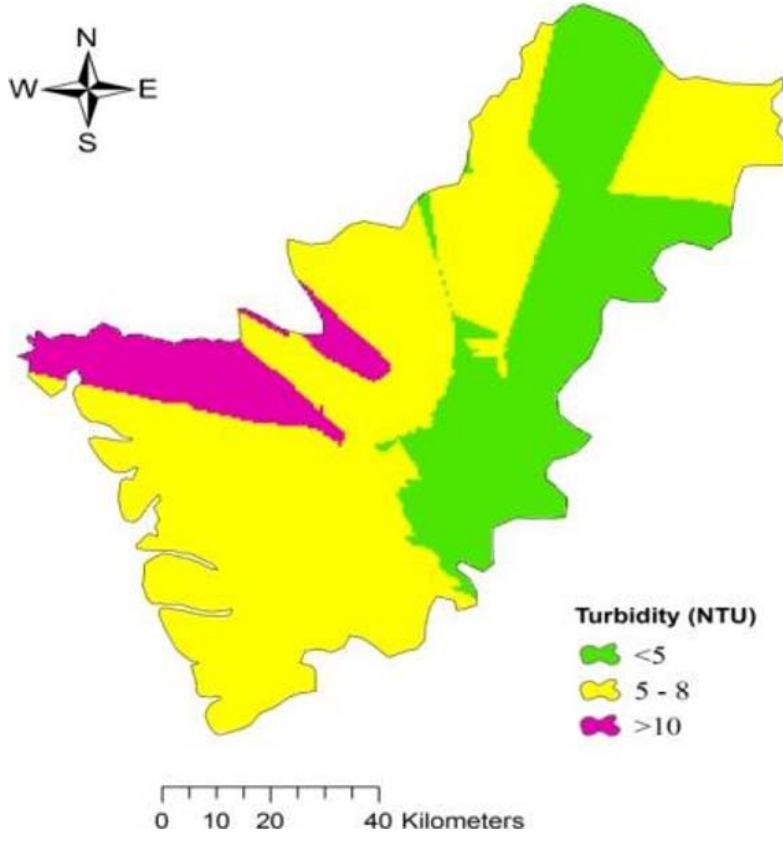

FIG. 4. SPATIAL TURBIDITY DISTRIBUTION IN THE STUDY AREA
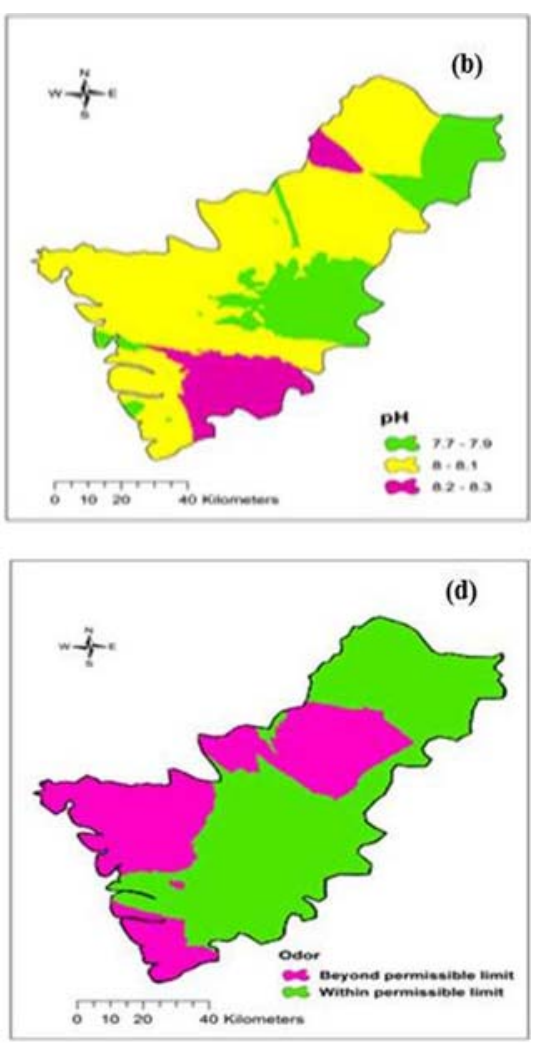

FIG. 3. SPATIAL DISTRIBUTION OF TASTE (a), pH (b), COLOR (c), AND ODOR (d) IN THE GROUNDWATER OF THE STUDY AREA

Mehran University Research Journal of Engineering \& Technology, Volume 36, No. 4, October, 2017 [p-ISSN: 0254-7821, e-ISSN: 2413-7219] 


\subsection{Calcium}

The calcium is one of the fundamental parameters available in different types of rocks. Its maximum permissible limit in water for drinking purpose is $75 \mathrm{mg} / \mathrm{l}$ [30]. In the study area, the concentration of calcium ranged from 34-883 $\mathrm{mg} / \mathrm{l}$ with an average value of $163 \mathrm{mg} / \mathrm{l}$. The spatial distribution of calcium concentration in the groundwater of the study area is shown in Fig. 6. The spatial distribution indicated that calcium concentration was very high in the study area, which may be due to seawater intrusion in coastal aquifers of the study area.

\subsection{Magnesium}

Magnesium is another fundamental parameter available in different types of rocks. Its maximum permissible limit in water for drinking purpose is $50 \mathrm{mg} / \mathrm{l}$ [30]. However, in the study area, its concentration ranged from 24-156 mg/ l with an average value of $56 \mathrm{mg} / \mathrm{l}$. The spatial distribution of magnesium in the groundwater of the study areais shown in Fig. 7. The spatial distribution shows that there

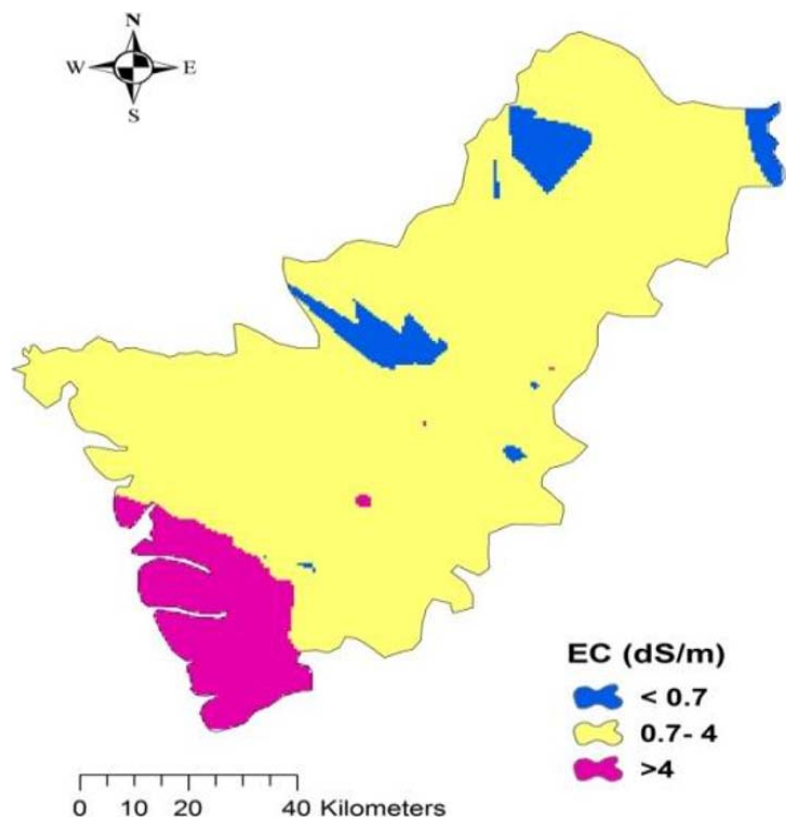

FIG. 5. SPATIAL DISTRIBUTION OF EC IN THE GROUNDWATER OF THE THATTA DISTRICT was a high concentration of magnesium in many places of the study area which may be due to the geological formation of aquifers.

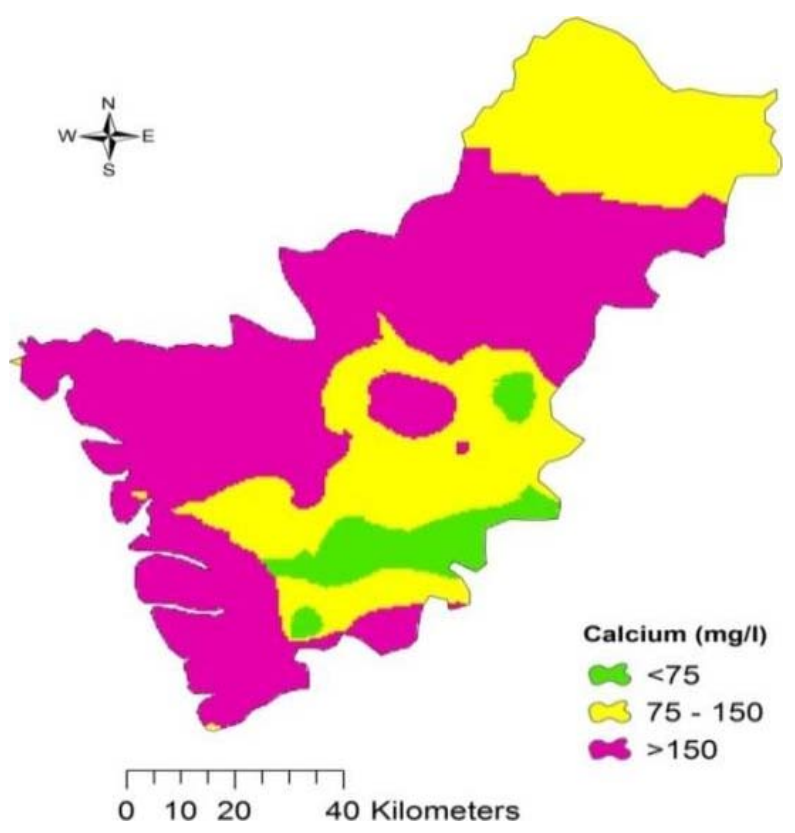

FIG. 6. SPATIAL DISTRIBUTION OF CALCIUM IN THE STUDY AREA

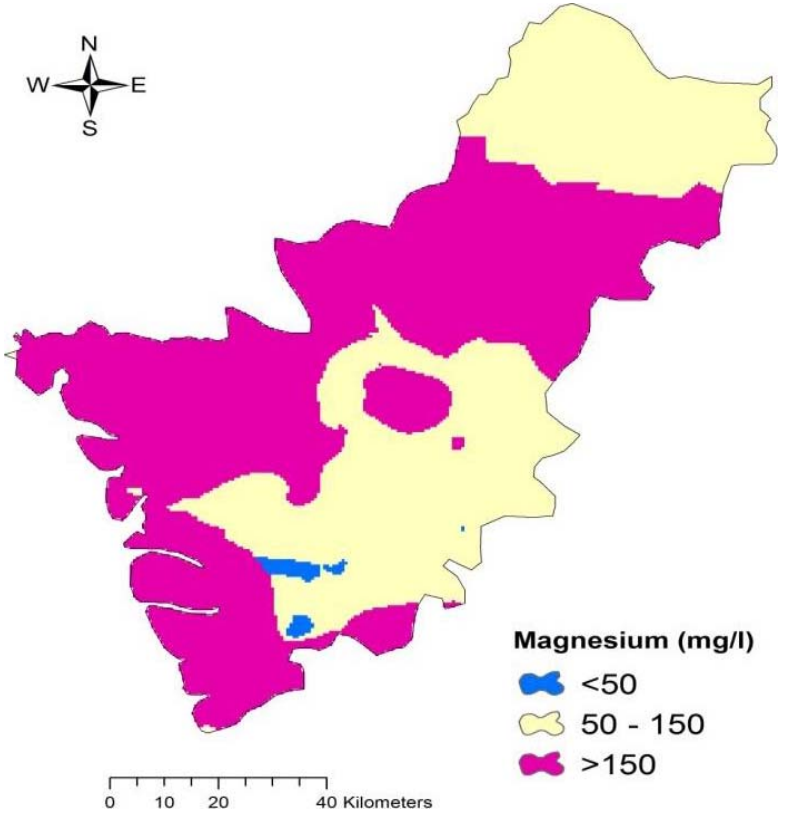

FIG. 7. SPATIAL DISTRIBUTION OF MAGNESIUM IN THE STUDY AREA

Mehran University Research Journal of Engineering \& Technology, Volume 36, No. 4, October, 2017 [p-ISSN: 0254-7821, e-ISSN: 2413-7219] 


\subsection{Total Hardness}

Hardness is an important parameter of water for its use in a domestic sector [2]. The calcium and magnesium are key parameters for total hardness. In the case of hard water, the excess use of soap is needed to achieve cleaning. Hardness affects the toxicity of many substances in the water [27]. As per WHO standards, the most desirable limit of total hardness for drinking purpose is $100 \mathrm{mg} / \mathrm{l}$ and the maximum acceptable limit is $500 \mathrm{mg} / \mathrm{l}$ [1]. According to Freeze and Cherry [42], the most desirable limit of TH for drinking water is $80-100 \mathrm{mg} / \mathrm{l}$. In the study area, the total hardness values ranged from 57-883 mg/l with a mean value of $216 \mathrm{mg} / \mathrm{l}$. In this case, just 11 samples out of 100 exceeded the maximum allowable limit of 500 mg/l. But according to Sawyer and McCarty [43], groundwater exceeding the cutoff limit of $300 \mathrm{mg} / \mathrm{l}$ is considered very hard. Such classification based on TH is given in Table 2.

The Table 2 shows that most the groundwater samples of the district fall in a hard water category. Around 60 samples out of 100 were considered as hard and need treatment before use for drinking purpose. The spatial distribution of $\mathrm{TH}$ in the groundwater of the study area is shown in Fig. 8. The spatial distribution shows that there was a high concentration of hardness especially in those places of the study area which are very close to the Arabian Sea.

\subsection{Chloride}

For potable water, maximum allowable limit of chloride concentration is $250 \mathrm{mg} / \mathrm{l}$. In the present study, groundwater samples were contaminated by chloride concentration from 372-6275 mg/l with a mean value of $1505 \mathrm{mg} / \mathrm{l}$. All the groundwater samples had chloride concentration beyond the allowable limit of $250 \mathrm{mg} / \mathrm{l}$. Chloride concentration in rainwater is usually under 10 mg/l, however, it might be high in coastal areas and in desert tracts [44]. The presence of chloride concentration beyond allowable limits in drinking water has a potential health impact, causes stomach discomfort, nose/eye irritation, and increases corrosive nature of water [29]. Fig. 9 describes the spatial variation of chloride concentration in the groundwater samples of the study area. Spatial distribution map shows that the chloride concentration in almost all places of the study area was

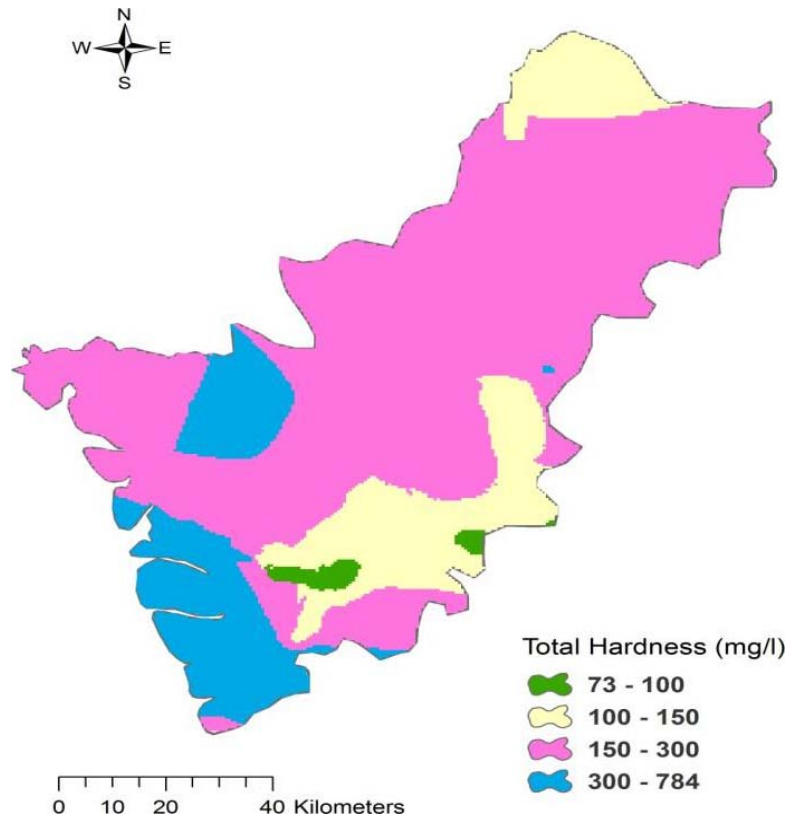

FIG. 8. SPATIAL DISTRIBUTION OF TOTAL HARDNESS IN THE STUDY AREA

TABLE 2. GROUNDWATER CLASSIFICATION BASED ON CONCENTRATION OF TOTAL HARDNESS

\begin{tabular}{|c|c|c|c|}
\hline Total Hardness (mg/l) & Classification & No. of Samples & Samples (\%) \\
\hline $0-75$ & Soft & 03 & 03 \\
\hline $75-150$ & Moderately hard & 60 & 26 \\
\hline $150-300$ & Hard & 11 & 60 \\
\hline$>300$ & Very hard & 11 \\
\hline
\end{tabular}

Mehran University Research Journal of Engineering \& Technology, Volume 36, No. 4, October, 2017 [p-ISSN: 0254-7821, e-ISSN: 2413-7219] 
beyond the allowable limits. The presence of higher concentration of chlorides in the groundwater samples of the study area can be used as an indication of seawater intrusion in the district [45].

\subsection{Total Dissolved Solids}

The concentration of TDS in water is a general sign used to decide the suitability of water for drinking as well as irrigation purpose. The maximum permissible limit of TDS in water for drinking purpose as per WHO standards is $500 \mathrm{mg} / \mathrm{l}$. For the present study, only $15 \%$ of groundwater samples had TDS concentration within the allowable limit of $500 \mathrm{mg} / \mathrm{l}$ and the rest (85\%) had very high concentration of TDS ranged up to $16704 \mathrm{mg} / \mathrm{l}$ with a mean value of 1517 mg/l. The highest value of TDS (16704 mg/l) was observed in the union council of Keti Bandar. The presence of a very high concentration of TDS indicates excessive entry of ionic matter and salts into the aquifers of the district. A few processes may be responsible for increased percentages of dissolved minerals in groundwater including seawater intrusion [45]. The higher

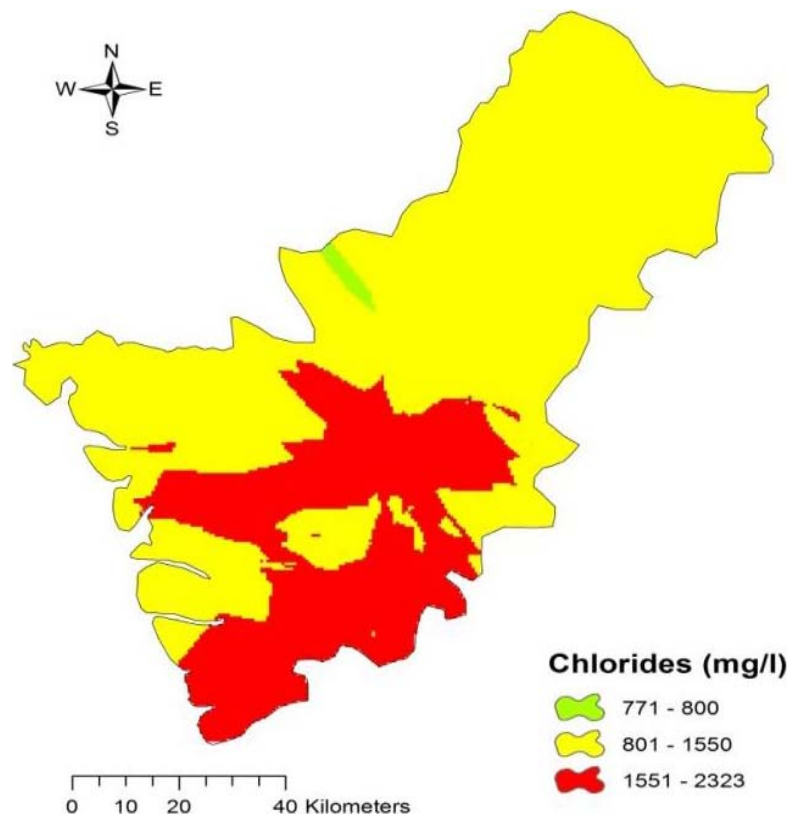

FIG. 9. SPATIAL DISTRIBUTION OF CHLORIDE IN THE STUDY AREA concentration of TDS causes undesirable taste, gastrointestinal irritation, corrosion or incrustation [27]. The spatial distribution of dissolved solids in the groundwater of district Thattais shown in Fig. 10. Spatial distribution map shows the highest values of TDS in many places of the study area which are probably close to the Arabian Sea.

\subsection{Arsenic}

Analysis of groundwater samples revealed that about $20 \%$ of groundwater samples were contaminated with arsenic ranged up to $150 \mathrm{ppb}$, whereas according to WHO [30], its maximum acceptable limit for drinking water is $5-10 \mathrm{ppb}$. The presence of arsenic concentration in groundwater in some areas of the district reflects an alarming situation for the people of the area who use toxic groundwater. The alarming results of arsenic concentration in groundwater indicated a nonlinear trend but its concentration varied considerably from location to location. The presence of arsenic contamination beyond permissible limit causes cancer, liver,

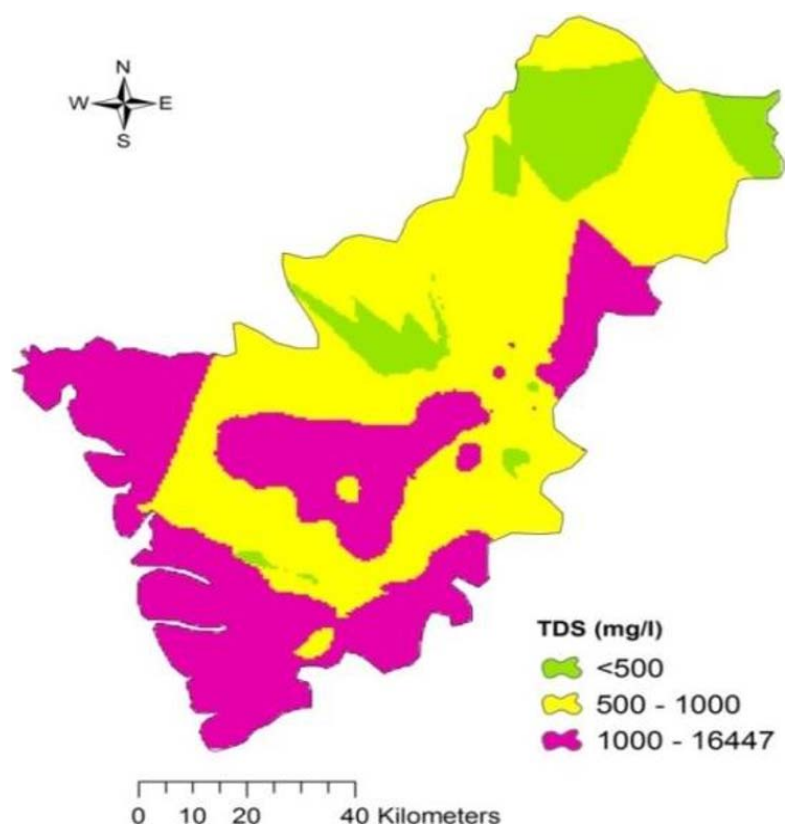

FIG. 10. SPATIAL DISTRIBUTION OF DISSOLVED SOLIDS IN THE STUDY AREA

Mehran University Research Journal of Engineering \& Technology, Volume 36, No. 4, October, 2017 [p-ISSN: 0254-7821, e-ISSN: 2413-7219] 
cardiovascular, neuropathies and ocular diseases [46]. One of the possible sources of arsenic pollution of groundwater might be due to the topographical arrangement of sub-strata of the area which contains adequate amounts of the arsenic component. Areas having aquifers with arsenic enriched geological formation might have groundwater contaminated with arsenic. Fig. 11 demonstrates the spatial variation of arsenic in the groundwater of the study area. The spatial distribution shows that in some union councils such as Buhara, Gaarho, Sukhpur, Mahar, Kotri Allah Rakhio Shah, Karampur, Ghulamullah, Chhatochand, Uddasi, Mirpur Sakro, etc. of the district, the arsenic concentration was beyond the permissible limits set by WHO [30].

\subsection{Overall Groundwater Quality with Respect to WHO's Permissible Limits}

Overall summary of groundwater analysis with different water quality parameters lying beyondWHO's permissible limits is given in Table 3 .
Spatial correlation between various groundwater quality parameters was tried to develop but in almost all the cases a non-significant trend was observed. However, there was a strong relation between Calciumand $\mathrm{TH}$ with a coefficient of determination of $\mathrm{R}^{2}=0.96$ regression with regression Equation(1) as shown in Fig. 12.

$\mathrm{TH}=58.574+0.9748 \times \mathrm{Ca}$

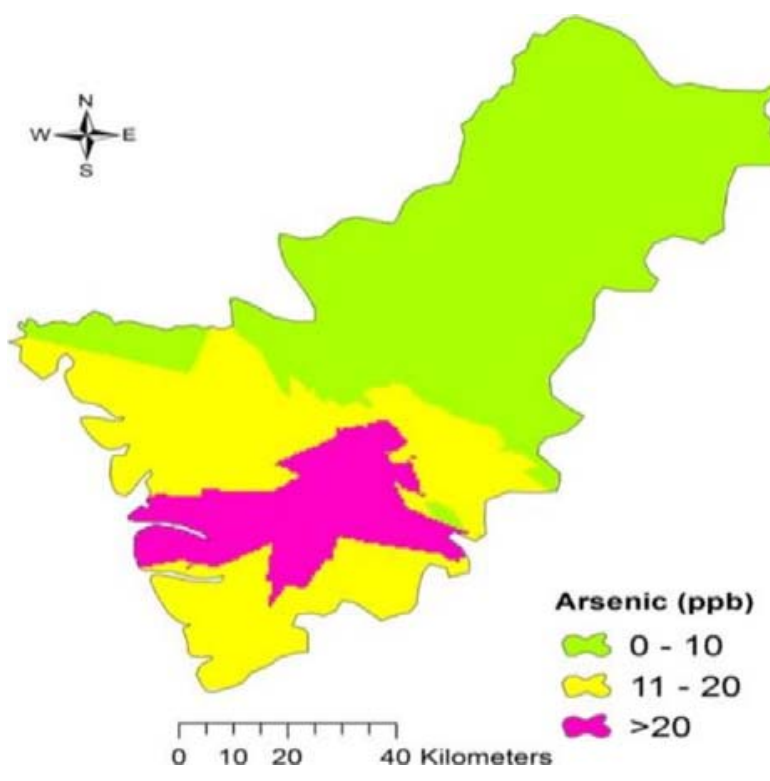

FIG. 11. SPATIAL ARSENIC DISTRIBUTION IN THE STUDY AREA

TABLE 3. GROUNDWATER SAMPLES WITH VARIOUS WATER QUALITY PARAMETERS BEYOND WHO'S PERMISSIBLE LIMITS IN DISTRICT THATTA

\begin{tabular}{|c|c|c|c|}
\hline Parameter & Permissible Limit & Total No. Of Samples & $\begin{array}{c}\text { No. of Samples Beyond } \\
\text { Permissible Limit }\end{array}$ \\
\hline Taste (Bitter, Salty, Sour and Sweet) & Unobjectionable & 100 & 55 \\
\hline Color & 15 TCU & 100 & 16 \\
\hline Odor & Odourless & 100 & 88 \\
\hline Electric Conductivity & $0.7 \mathrm{dS} / \mathrm{m}$ & 100 & 09 \\
\hline pH at 250C & $6.5-8.5$ & 100 & 85 \\
\hline Total Dissolved Solids & $500(\mathrm{mg} / \mathrm{l})$ & 100 & 100 \\
\hline Chloride & $250(\mathrm{mg} / \mathrm{l})$ & 100 & 85 \\
\hline Calcium & $75(\mathrm{mg} / \mathrm{l})$ & 100 & 52 \\
\hline Magnesium & $50(\mathrm{mg} / \mathrm{l})$ & 100 & 11 \\
\hline Total Hardness & $500(\mathrm{mg} / \mathrm{l})$ & 100 & 30 \\
\hline Turbidity & $5 \mathrm{NTU}$ & 100 & 20 \\
\hline Arsenic & $10(\mathrm{ppb})$ & 100 & \\
\hline
\end{tabular}

Mehran University Research Journal of Engineering \& Technology, Volume 36, No. 4, October, 2017 [p-ISSN: 0254-7821, e-ISSN: 2413-7219] 


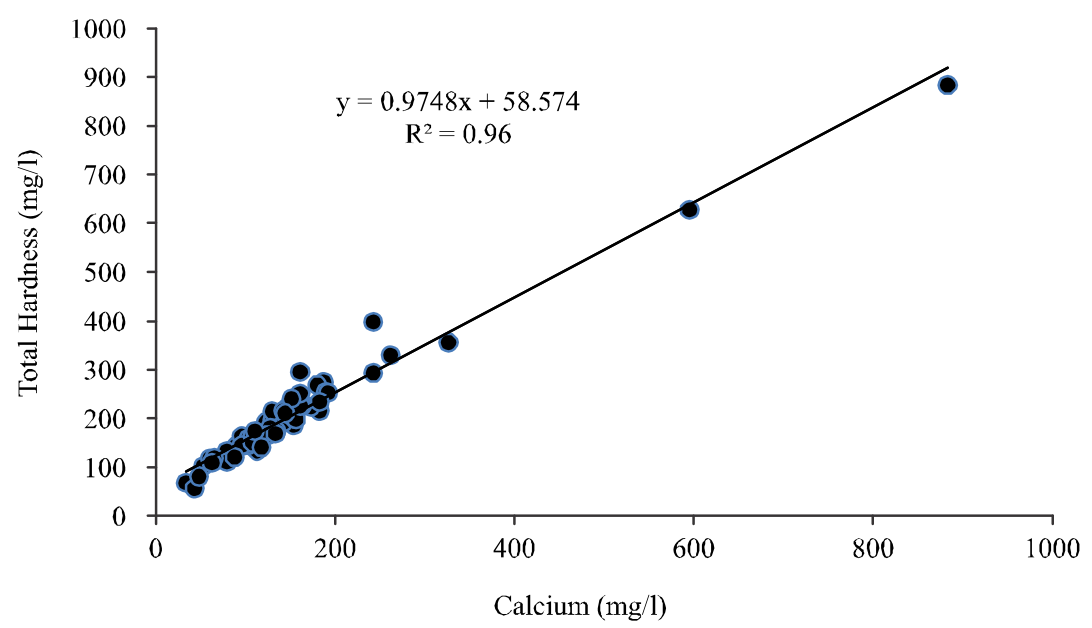

FIG. 12. CORRELATION BETWEEN CALCIUM AND TOTAL HARDNESS

\section{CONCLUSION}

The groundwater quality analysis of Thatta district indicated that $55 \%$ of the groundwater samples had bitter and salty taste, while $16 \%$ water samples had color values greater than the permissible limit of 15 TCU. Similarly, $85 \%$ of the total samples had TDS beyond permissible limit of $500 \mathrm{mg} / \mathrm{l}$, while $30 \%$ samples had turbidity values beyond permissible limit of 5 NTU. However, all the groundwater samples had chloride concentration beyond the WHO's permissible limit. The calcium concentration was also more than the permissible limit of $75 \mathrm{mg} / \mathrm{l}$ in $85 \%$ samples, while $52 \%$ samples showed higher values of magnesium. Based on total hardness, only 03 samples were considered as soft, 26 moderately hard, 60 hard and 11 very hard. However, odor and $\mathrm{pH}$ in most of the groundwater samples were within unobjectionable limits for human consumption. Analysis for arsenic revealed that $20 \%$ of groundwater samples had a concentration higher than the safe limit of $10 \mathrm{ppb}$, which is an alarming situation for the people of the district who use such toxic water for drinking purpose.

GIS maps of groundwater quality for various physicochemical parameters also indicated that in most of the areas of the district, especially coastal areas, the groundwater was not satisfying the water quality standards set by WHO, hence not suitable for drinking purpose. Proper treatment before use for drinking purpose is recommended.

\section{ACKNOWLEDGEMENT}

The US-Pakistan Center for Advanced Studies in Water, Mehran University of Engineering \& Technology, Jamshoro, Pakistan, is gratefully acknowledged for funding the project "Climate Change: Assessing impact of seawater intrusion on Soil, Water and Environment in Indus Delta using GIS and Remote Sensing tools” under the Applied Policy Research Grants.

\section{REFERENCES}

[1] Balakrishnan, P., Saleem, A., and Mallikarjun, N.D., “Groundwater Quality Mapping Using Geographic Information System (GIS): A Case Study of Gulbarga City, Karnataka, India”, African Journal of Environmental Science and Technology, Volume 5, No. 12, pp. 1069-1084, 2011.

[2] Rajesh, J., Lakshumanan, C., Govindaraj, V., and Karthick, P., "Environmental Impacts Assessment of Brackish Water Aquaculture Activity in Nagapattinam Region, South East Coast of India”, Journal of Environmental and Analytical Toxicology, Volume 6, pp. 367, 2016. 
[3] Yihdego, Y., and Paûard, A.,’Hydro-Engineering Solution for a Sustainable Groundwater Management at a CrossBorder region: Case of Lake Nyasa/Malawi Basin, Tanzania”, International Journal of Geo-Engineering, Volume, 7, No.1, pp. 1-20, 2016.

[4]

El-Kadi, A.I., Tillery, S., Whittier, R.B., Hagedorn, B., Mair, A., Ha, K., and Koh, G., “Assessing Sustainability of Groundwater Resources on Jeju Island, South Korea, under Climate Change, Drought, and Increased Usage”, Hydrogeology Journal, Volume, 22, No. 3, pp. 625-642, 2014

[5] Akbar, A., Sitara, U., Khan, S.A., Muhammad, N., Khan, M.I., Khan, Y.H., and Kakar, S.R., "Drinking Water Quality and Risk of Water-Borne Diseases in the Rural Mountainous Area of Azad Kashmir Pakistan”, International Journal of Biosciences, Volume 3, No. 12, pp. 245-251, 2013.

Haydar, S., Arshad, M., and Aziz, J.A., "Evaluation of Drinking Water Quality in Urban Areas of Pakistan: A Case Study of Southern Lahore, Pakistan”, Journal of Engineering and Applied Science, Volume 5, pp. 16-23, 2009.
Small, C., and Nicholls, R.J., “A Global Analysis of Human Settlement in Coastal Zones”, Journal of Coastal Resources, Volume 19, pp. 584-599, 2003.

Don, N.C., Hang, N.T.M., Araki, H., Yamanishi, H., and Koga, K., "Groundwater Resources Management Under Environmental Constraints”, Journal of Environmental Geology, Volume 49, pp. 601-609, 2006.

Trabelsi, R., MoncefZairi, M., and Dhia, H.B., "Groundwater Salinization of the Sfax Superficial Aquifer, Tunisia”, Journal of Hydrogeology, Volume 157, pp. 1341-1355, 2007.

Sherif, M., Kacimov, A., Javadi, A., and Ebraheem, A.Z., "Modeling Groundwater Flow and Seawater Intrusion in the Coastal Aquifer of Wadi Ham UAE”, Journal of Water Resources Management, Volume 26, pp. 751-774, 2012.

Abd-Elhamid, H., and Javadi, A., "A Cost-Effective Method to Control Seawater Intrusion in Coastal Aquifers”, Journal of Water Resources Management, Volume 25, pp. 2755-2780, 2011.
[12]

Oude Essink, G.H.P., Van Baaren, E.S., and De Louw, P.G.B., "Effects of Climate Change on Coastal Groundwater Systems: A Modeling Study in the Netherlands”, Journal of Water Resources Research, Volume 46, W00F04, 2010.

[13] Ferguson, G., and Gleeson, T., "The Vulnerability of Coastal Aquifers to Groundwater use and Climate Change", Nature Climate Change, Volume 2, pp. 342-345, 2012.

[14] Sreekanth, J., and Datta, B., "Multi-Objective Management of Saltwater Intrusion in Coastal Aquifers Using Genetic Programming and Modular Neural Network-Based Surrogate Models”, Journal of Hydrology, Volume 393, pp. 245-256, 2010.

[15] White, N.J., Church, J.A., and Gregory, J.M., "Coastal and Global Averaged Sea Level Rise for 1950-2000”, Journal of Geophysical Research Letters, Volume 32, L01601, 2005.

[16] Sanford, W.E., and Pope, J.P., "Current Challenges Using Models to forecast Seawater Intrusion, Lessons from the Eastern Shore of Virginia, USA", Journal of Hydrogeology, Volume 18, pp. 73-93, 2010.

[17] Clasen, T., Cairncross, S., Haller, L., Bartram, J., and Walker, D., "Cost-Effectiveness of Water Quality Interventions for Preventing DiarrhoealDisease in Developing Countries”, Journal of Water and Health, Volume 5, No.4, 599-608, 2007.

[18] Lee, E.J., and Schwab, K.J., "Deficiencies in Drinking Water Distribution Systems in Developing Countries”, Journal of Water and Health, Volume 3, No. 2, pp. 109-127, 2005.

[19] Ishaque, M., and Khan, A.A., "Prevalence of Dental Caries and Oral Hygiene Habits of Children in Quetta, Pakistan”, Pakistan Oral and Dental Journal, Volume 21, No. 1, pp. 60-63, 2001.

[20] Stephenson, L.S., Latham, M.C., and Ottesen, E.A., "Malnutrition and Parasitic Helminth Infections", Journal of Parasitology, Volume 121, pp. 23-28, 2000.

[21] Dillingham, R., and Guerrant, R.L., "Childhood Stunting: Measuring and Stemming the Staggering Costs of Inadequate Water and Sanitation”, Journal of Lancet, Volume 363, pp. 94-95, 2004. 
[22] WWF, "Pakistan's Waters at Risk, Water and Health Related Issues and Key Recommendations”, World Wild Fund, Pakistan, 2007.

[23] Tahir, M.A., Chandio, B.A., Abdullah, M., and Rashid, A., "Drinking Water Quality Monitoring in the Rural Areas of Rawalpindi”, Proceedings of National Workshop on Quality of Drinking Water, Islamabad: Pakistan Council of Research in Water Resources, pp. 35-39, 1998.

[24] Tahir, M.A., and Rashid, A., "Performance of Local water Decontamination Product”, Journal of Drainage and Water Management, Volume 1, pp. 70-74, 1997.

[25] World Bank, Pakistan; "Strategic Country Environmental Assessment: Rising to the Challenges", Document of the World Bank,Report No. 36946-PK, August, 2006.

[26] Memon, M., Soomro, M.S., Akhtar, M.S., and Memon, K.S.,”Drinking Water Quality Assessment in Southern Sindh (Pakistan)”, Environment Monitoring Assess, Volume 177, pp. 39-50, 2011.

Husain, V., Nizam, H., and Arain, G.M., "Arsenic and Fluoride Mobilization Mechanism in Groundwater of Indus Delta and the Thar Desert, Sindh, Pakistan”, International Journal of Economic Environmental Geology, Volume 3, No.1, pp.15-23, 2012.

Rubab, G., Naseem, S., Khan, A., Husain, V., and Arain, G.M., "Distribution and Sources of Arsenic Contaminated Groundwater in Parts of Thatta District, Sindh”, Journal of Himalayan Earth Sciences, Volume 47, No. 2, pp. 175-183, 2014.

[29] Patil, P.N., Sawant, D.V., and Deshmukh, R.N.,’PhysicoChemical Parameters for Testing of Water-A Review", International Journal of Environmental Sciences, Volume 3, No. 3, pp. 1194-1207, 2012.

[30] WHO (World Health Organization), "Guidelines for Drinking Water Quality”, 4th Edition, Geneva, Switzerland, 2011.

[31] Majidano, S.A., Arain, G.M., Bajaj, D.R., Iqbal, P., and Khuhawar, M.Y., “Assessment of Groundwater Quality with a Focus on Arsenic Contents and Consequences, A Case Study of TandoAllahyar District in Sindh Province”, International Journal of Environmental Engineering, Volume 1, pp. 91-96, 2010.
[32] Husain, V., "Sindh Education Reform Program (SERP), Drinking Water Quality Component”, Study for World Bank, File Report, 2009.

[33] Arain, G.M., Aslam, M., and Majidano, S.A., "Arsenic Contamination of Underground Water in District Matiari and Khairpur”, Journal of Chemical Society Pakistan, Volume 29, No. 5, pp. 463-467, 2007.

[34] Skidmore, A.K., Bijer, W., Schmidt, K., and Kumar, L., "Use of Remote Sensing and GIS for SustainableLand Management”, ITC Journal, Volume 3, No.4, pp. 302-316, 1997.

[35] Majeed, S., Zaman, S.B., Ali, I., and Ahmed, S., "Situational Analysis of Sindh Coast Issues and Options", Managing National Resources for future Agriculture, Research Briefings, Volume 2, No.11, 2010.

[36] ADB and IUCN, "Regional Technical Assistance for Coastal and Marine Resources Management and Poverty Reduction in South Asia: Situation Analysis Report, RETA 5974-PAK”, Asian Development Bank and the International Union for Conservation of Nature, 2002.

[37] Giosan, L., Constantinescu,S., Clift, P.D.,Tabrez, A.R., Danish, M., and Inam, A., "Recent Morphodynamics of the Indus Delta Shore and Shelf”, Continental Shelf Research, Volume 26, pp. 1668-1684, 2006.

[38] McArthur, J.M., Ravenscroft, P., Safiulla, S., and Thinwall, M.F., “Arsenic in Groundwater: Testing Pollution Mechanisms for Sedimentary Aquifers in Bangladesh”, Water Resources Research, Volume 37, pp.109-117, 2001.

[39] Nickson, R.T., McArthur,J.M., Shrestha, B.R.,KyawMyint, T.O., and Lowry, D., “Arsenic and other DrinkingWater Quality Issues, Muzaffargarh District, Pakistan”, Journal of Applied Geochemistry, Volume 20, pp. 55-68, 2005.

[40] Sivakumar, S., Ponnambalam, K., and Chokkalingam, L., "Estimation of Carbon Stock in above Ground Biomass. In: Muthupet Mangrove, Southeast Coast of India”, International Journal of Intellectual Advancements and Research in Engineering Computations, Volume 2, pp. 139-150, 2011. 
[41] Santhiya, G., Lakshumanan, C., and Muthukumar, S., "Mapping of Landuse/Land Cover Changes of Chennai Coast and Issues Related to Coastal Environment Using Remote Sensing and GIS”, International Journal of Geometrics and Geosciences, Volume 1, No. 3, pp. 563-576, 2010.

[42] Freeze, R.A., and Cherry, J.A., "Groundwater”, New Jersey: Prentice-Hall, 1979.

[43] Sawyer, C.N., and McCarty, P.L., "Chemistry for Sanitary Engineers”, $2^{\text {nd }}$ Edition,McGraw-Hill Education, New York, 1967.

[44] Karanth, K.R., “Groundwater Assessment Development and Management”, Handbook, Tata McGraw-Hill, New Delhi, India, 2004.
[45] Supriyadi, K., and Putro, A.S.P., "Geophysical and Hydrochemical Approach for Seawater Intrusion in North Semarang, Central Java, Indonesia”,International Journal of Geomate, Volume 12, No.31, pp. 134-140, 2017.

[46] Das, N., Paul, S., Chatterjee, D., Banerjee, N., Majumder, N.S., Sarma, N., Sau, T.J., Basu, S., Banerjee, S., Majumder, P., Bandyopadhyay, A.K., States, J.C., and Giri, A.K., “Arsenic Exposure through Drinking Water Increases the Risk of Liver and Cardiovascular Diseases in The Population of West Bengal, India”, BMC Public Health Journal, Volume 12, No. 639, 2012. http:// www.biomedcentral.com/1471-2458/12/639 